\title{
KESEDIAAN MEMBAYAR (WILLINGNESS TO PAY) KONSUMEN MILENIAL DALAM MENGKONSUMSI SAYURAN ORGANIK (Suatu Kasus pada Warung Sehat 1000 Kebun, Kota Bandung)
}

\author{
AVAILABILITY TO PAY (WILLINGNESS TO PAY) MILLENIAL CONSUMERS \\ IN CONSUMING ORGANIC VEGETABLES \\ (A Case in Warung Sehat 1000 Kebun, Bandung City)
}

\author{
Bagus Imran Saptadji Handoko*, Iwan Setiawan \\ Program Studi Agribisnis, Fakultas Pertanian, Universitas Padjadjaran \\ Jl. Raya Jatinangor Sumedang Km. 21 \\ *Email: bagus16006@mail.unpad.ac.id \\ (Diterima 20-1-2021; Disetujui 27-1-2021)
}

\begin{abstract}
ABSTRAK
Penyakit tidak menular saat ini menjadi penyebab dominan yang mengakibatkan kematian di Indonesia. Penyakit tidak menular tersebut selalu mengalami peningkatan. Salah satu penyebab penyakit tidak menular tersebut diakibatkan oleh pola konsumsi yang tidak sehat, antara lain banyaknya mengkonsumsi makanan cepat saji. Meningkatnya pengetahuan masyarakat generasi milenial terhadap pentingnya kesehatan, ditandai dengan munculnya rasa peduli akan hidup sehat dengan mengkonsumsi pangan organik. Pangan organik yang banyak ditemui sekarang ini adalah sayuran organik, yang memiliki peranan penting bagi kesehatan sehingga sering dikonsumsi sebagai pelengkap makanan pokok. Berdasarkan permasalahan tersebut penelitian ini bertujuan untuk mengetahui kesediaan membayar (willingness to pay) konsumen milenial dalam mengkonsumsi sayuran organik di Warung Sehat 1000 Kebun. Penelitian ini menggunakan desain penelitian kuantitatif dan metode survei dengan menggunakan kuesioner sebagai alat bantu dalam melakukan wawancara. Analisis yang digunakan pada penelitian ini adalah uji validitas, uji reliabilitas, analisis statistik deskriptif, analisis regresi linier berganda dan Contingent Valuation Method (CVM). Hasil penelitian menjawab bahwa faktor yang paling tinggi pengaruhnya terhadap kesediaan membayar konsumen generasi milenial yaitu faktor psikologis, secara signifikan berpengaruh terhadap kesediaan membayar bagi konsumen dalam mengkonsumsi sayuran organik.
\end{abstract}

Kata kunci: Sayuran Organik, Generasi Milenial, Kesediaan Membayar

\begin{abstract}
Non-infectious diseases are now the dominant cause of deaths in Indonesia and the numbers are increasing each year. One of the causes of these non-infectious diseases is unhealthy consumption patterns, such as consuming a massive amount of fast foods. Increased awareness within the general public especially the millennial generation about the importance of health is shown through the emergence of a sense of caring for a healthy life by consuming organic food. Organic foods that are mostly found today are organic vegetables, which have an important role for health, thus they are often consumed as a complement to staple foods. Based on these issues, this study aims to determine how willing are the millennials to pay for organic vegetables at Warung Sehat 1000 Kebun. This study is conducted through quantitative research and survey methods using questionnaires as the instrument to conduct interviews. The analysis method used in this study is the validity test, reliability test, descriptive statistical analysis, multiple linear regression analysis and Contingent Valuation Method (CVM). The results showed that the factors that most influenced the willingness of consumers who created millennials were psychological factors, which significantly affected consumers' willingness to consume organic vegetables.
\end{abstract}

Keywords: Organic Vegetables, Millennial Generation, Willingness to Pay 


\section{PENDAHULUAN}

Era digital saat ini penelitian mengenai generasi milenial atau yang kita ketahui sebagai generasi Y menjadi hal yang menarik untuk dijadikan topik penelitian. Rendahnya angka kesakitan yang ada pada generasi milenial menjadi hal yang harus dipertahankan (Gambar 1). Kementerian Pemberdayaan Perempuan dan Perlindungan Anak bekerjasama dengan Badan Pusat Statistik (2018) menyimpulkan generasi Y merupakan penduduk yang lahir pada tahun 1980-2000.

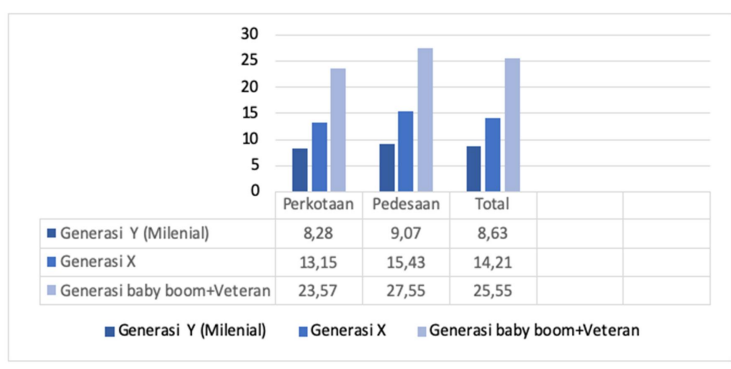

Gambar 1. Angka Kesakitan Penduduk Indonesia Menurut Generasi dan Daerah Tempat Tinggal (Sumber: Survei Sosial Ekonomi Nasional (Susenas), Badan Pusat Statistik 2017)

Berdasarkan data World Health Organization (WHO) tahun 2011 menyatakan penyebab kematian di negara-negara berkembang sebesar $60 \%$ diakibatkan oleh penyakit tidak menular. Di Indonesia, menurut Riset Kesehatan Dasar (Riskesdas) tahun 2018 menyebutkan, penyakit tidak menular mengalami kenaikan jika dibandingkan dengan Riskesdas 2013, antara lain kanker, stroke, penyakit ginjal kronis, diabetes melitus, dan hipertensi. Prevalensi kanker naik dari 1,4\% (Riskesdas, 2013) menjadi 1,8\%; prevalensi stroke naik dari $7 \%$ menjadi $10,9 \%$; dan penyakit ginjal kronis naik dari $2 \%$ menjadi $3,8 \%$. Kenaikan prevalensi penyakit tidak menular ini berhubungan dengan pola hidup, antara lain merokok, konsumsi minuman beralkohol, dan aktivitas fisik. Penyakit tersebut dapat disebabkan karena sering mengkonsumsi makanan cepat saji (junkfood). Hal ini didukung survei dampak dari junkfood jika dikonsumsi terlalu banyak, kemungkinan bisa menyebabkan penyakit jantung, diabetes, tekanan darah dan penyakit hati (Rosmauli \& Wuri, 2012).

Globalisasi berperan terhadap perubahan pola konsumsi masyarakat, salah satunya adalah kebiasaan mengkonsumsi junk food telah menjadi gaya hidup baru di kalangan generasi milenial. Hal ini didukung dari hasil Statistik Gender Tematik, Profil Generasi Milenial Indonesia Tahun 2018 menjelaskan angka kesakitan generasi milenial lebih banyak dipengaruhi oleh konsumsi makanan cepat saji (junk food) yang semakin mudah ditemui. 
Saat ini Masyarakat Indonesia dalam kesadaran pentingnya kualitas hidup merupakan salah satu hal yang perlu di perhatikan (Monica Priscilia A, 2014). Khususnya pada generasi milenial dalam memperhatikan kualitas hidupnya semakin berubah serta berkembangnya tingkat pendidikan masyarakat golongan milenial membuat konsumen memperbaiki gaya hidup mereka ke arah yang lebih sehat, sehingga sebagian besar masyarakat golongan milenial mulai memikirkan segi kualitas, kebersihan, dan keamanan makanan yang bebas dari zatzat berbahaya bagi kesehatan. Hal ini disampaikan melalui penelitian yang dilakukan oleh (Mintel, 2009) bahwa generasi milenial tidak sembarangan dalam memilih makanan. Mereka cenderung memilih makanan yang bersih, organik, dan alami.

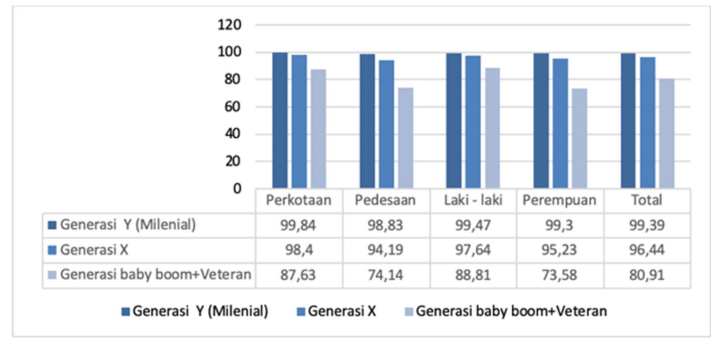

Gambar 2. Angka Melek Huruf Penduduk Indonesia Menurut Generasi, Daerah Tempat Tinggal, dan Jenis Kelamin (Sumber: Survei Sosial Ekonomi Nasional (Susenas Badan Pusat Statistik, 2017)

Berdasarkan gambar grafik diatas dapat dlihat bahwa tingkat perubahan kondisi pendidikan dalam dua dekade terlihat dari indikator angka melek huruf menurut kelompok generasi. Pada tahun 2017, angka melek huruf penduduk generasi milenial paling tinggi dibandingkan dengan penduduk generasi $\mathrm{X}$ dan generasi Baby Boom + Veteran. Generasi milenial yang dapat membaca dan menulis hampir mendekati 100 persen, tepatnya sebesar 99,39 persen. Sedangkan untuk generasi $\mathrm{X}$ sebesar 96,44 persen dan Generasi Baby Boom + Veteran sebesar 80,91 persen. Ini mengindikasikan bahwa sistem pendidikan dasar saat ini telah berjalan dengan baik.

Melihat fenomena di atas, seharusnya generasi milenial mulai menerapkan cara pola hidup sehat dengan mulai mengkonsumsi makanan organik dan meninggalkan pola konsumsi yang tidak sehat yaitu makanan yang mengandung bahan kimia karena, produk organik diproduksi tanpa adanya input bahan kimia seperti, pestisida dan pupuk sintetis, rekayasa genetik, antibiotik, hormon pertumbuhan, bahan pengawet, atau pewarna (Kementerian Pertanian Badan Litbang Pertanian, 2002). Hal ini didukung oleh survei yang lakukan oleh Aviva pada 2018, lebih dari $3 / 4$ golongan milenial tertarik untuk makan makanan yang lebih sehat. 
Menurut IFOAM (International Federation for Organic Agriculture Movement, 2005) mengatakan salah satu pangan organik yang banyak ditemui sekarang ini adalah sayuran organik. Sayuran organik merupakan produk tanaman sayur-sayuran yang banyak digemari untuk dikembangkan pada pertanian organik. Selain itu sayuran organik memiliki peranan penting bagi kesehatan sehingga sering dikonsumsi sebagai pelengkap makanan pokok (Setyowati et.al, 1992). Potensi pasar pertanian organik didukung oleh konsumsi masyarakat terhadap sayuran. Peningkatan pendapatan mendorong masyarakat untuk melengkapi kebutuhan tubuh dengan mengkonsumsi makanan yang sehat (Nis Made Tisnawati, 2015).

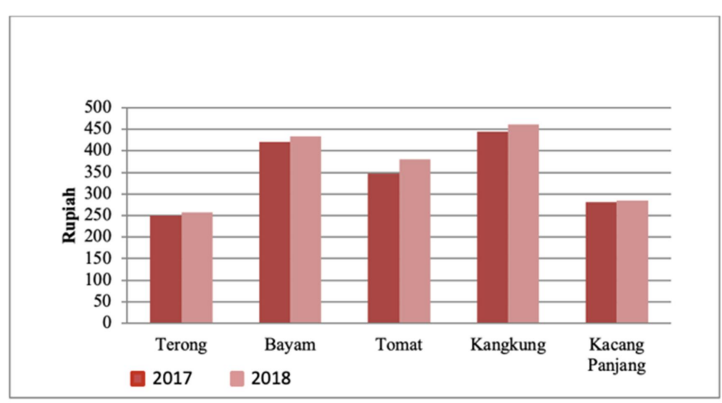

Gambar 3. Pengeluaran Rata-rata per Kapita Seminggu Untuk Mengkonsumsi Sayuran di Indonesia (Sumber: Badan Pusat Statistik, 2017; 2018).

Berdasarkan gambar di atas dapat dilihat bahwa tingkat konsumsi sayuran masyarakat mengalami kenaikan dari tahun 2018. Sayuran dengan konsumsi tertinggi yang termasuk dalam perhitungan data BPS tersebut adalah terong, bayam, tomat, kangkung, kacang panjang. Dari lima komoditas tersebut kenaikan rata-rata pengeluaran seminggu adalah sebesar Rp. 15, hal ini menunjukan bahwa masyarakat mulai sadar dalam mengkonsumsi sayuran.

Saat ini sayuran organik menjadi trend dan pilihan utama bagi masyarakat Dengan mengkonsumsi sayuran organik masyarakat menyadari bahwa banyak keunggulan dan manfaat bagi kesehatan konsumen dalam jangka panjang, maupun bagi lingkungan secara luas serta berkelanjutan (Leta Rafael Levis, 2019).

Untuk mendapatkan manfaat tersebut, konsumen bersedia membayar sayuran organik tersebut. Hal ini didukung oleh Vlosky et.al, 1999; Laroche et al., 2001, yang menyatakan bahwa konsumen yang mempunyai kesadaran tinggi akan lingkungan akan memilih produk-produk yang ramah lingkungan walaupun harganya relatif lebih mahal. Terdapat beberapa atribut yang dipertimbangkan oleh konsumen sayuran organik dalam membandingkan antara sayuran organik dengan sayuran non organik. Pada umumnya konsumen menilai kualitas suatu produk dari tampilannya (Beharrell \& Macfie, 1991). 
Saat ini sayuran organik yang terdapat di pasar modern Kota Bandung masih belum semua disertifikasi organik secara sah oleh lembaga sertifikasi di Indonesia. Sebagai contoh sayuran organik yang terdapat di Warung Sehat 1000 Kebun Arcamanik, Bandung masih belum semua yang disertifikasi dikarenakan harga sertifikasi untuk sayuran organik yang masih sangat mahal sehingga sayuran organik yang ada hanya menggunakan komponen dan kemasan organik yang mempunyai dampak minimal terhadap lingkungan seperti aman, tidak beracun, dapat didaur ulang, menggunakan kemasan yang ramah lingkungan untuk mengurangi dampak negatif konsumsi produk pada lingkungan. Hal yang dilakukan untuk menunjukkan bahwa sayuran tersebut adalah sayuran organik maka pada umumnya akan diberikan label organik pada setiap kemasan produk.

Warung Sehat 1000 Kebun Arcamanik, Bandung merupakan salah satu ritel modern di kota Bandung yang menyediakan berbagai macam sayuran organik. Terbentuk dari perwujudan atau menifestasi dan misi komunitas 1000 kebun. Komunitas 1000 kebun sendiri berdiri tanggal 2 Juni 2015. Komunitas ini memiliki misi diantaranya, mensosialisasikan gaya hidup sehat dan memudahkan akses masyarakat ke produk-produk sehat dan ramah lingkungan. Fenomena ini adalah bentuk aksi dari komunitas 1000 kebun dalam mewujudkan prinsip hidup sehat melalui media Warung Sehat 1000 Kebun.

Peran Warung Sehat 1000 Kebun yaitu sebagai media untuk mengenalkan produk pertanian organik kepada masyarakat umum dan memberikan edukasi nilai lebih kepada masyarakat bahwa dengan mereka membeli produk organik tidak disadari mereka telah membantu petani dan menjaga dan memanfaatkan sumber daya alam untuk berkelanjutan, dalam arti dapat di nikmati seperti saat ini oleh generasi mendatang.

Dengan adanya pemberian nilai lebih terhadap masyarakat, Warung Sehat 1000 Kebun yakin dan optimis bahwa adanya kesadaran prinsip hidup kearah yang lebih sehat, yaitu prinsip gaya hidup. Prinsip gaya hidup tersebut medukung dalam kesehatan jasmani dan rohani, tidak merusak lingkungan, serta memandang perbuatan dalam melakukan segala hal baik lingkungan secara fisik, lingkungan, sosial dan ekonomi di sekitar kita).

Warung Sehat 1000 Kebun menyediakan beberapa komoditas 
sayuran untuk memenuhi kebutuhan para konsumennya. selanjutnya terdapat data penjualan beberapa produk sayuran organik yang paling diminati oleh para konsumen di Warung Sehat 1000 Kebun pada bulan Januari sampai Mei 2019.

Tabel 1. Data Penjualan Produk Sayuran Organik pada Bulan Januari-Maret 2019 di Warung Sehat 1000 Kebun Bandung

\begin{tabular}{|c|c|c|c|c|}
\hline $\begin{array}{c}\text { Jenis } \\
\text { Sayuran }\end{array}$ & $\begin{array}{c}\text { Harga } \\
\text { (Rupiah) }\end{array}$ & $\begin{array}{c}\text { Januari } \\
2019\end{array}$ & $\begin{array}{c}\text { Februari } \\
2019\end{array}$ & $\begin{array}{c}\text { Maret } \\
2019\end{array}$ \\
\hline $\begin{array}{c}\text { Wortel } \\
\text { (per kg) }\end{array}$ & 24.000 & $31 \mathrm{~kg}$ & $23 \mathrm{~kg}$ & $35 \mathrm{~kg}$ \\
\hline $\begin{array}{c}\text { Tomat } \\
\text { (per kg) }\end{array}$ & 34.000 & $4 \mathrm{~kg}$ & $10.5 \mathrm{~kg}$ & $18 \mathrm{~kg}$ \\
\hline $\begin{array}{c}\text { Bayam } \\
\text { Hijau (per } \\
250 \text { gram) }\end{array}$ & 7.000 & $13.2 \mathrm{~kg}$ & $8 \mathrm{~kg}$ & $9 \mathrm{~kg}$ \\
\hline $\begin{array}{c}\text { Kentang } \\
\text { (per kg) }\end{array}$ & 34.000 & $22 \mathrm{~kg}$ & $13.5 \mathrm{~kg}$ & $15 \mathrm{~kg}$ \\
\hline $\begin{array}{c}\text { Pakcoy } \\
\text { (per } 250 \\
\text { gram) }\end{array}$ & 7.000 & $13 \mathrm{~kg}$ & $9 \mathrm{~kg}$ & $8 \mathrm{~kg}$ \\
\hline $\begin{array}{c}\text { Kangkung } \\
\text { (pack 250 } \\
\text { gram) }\end{array}$ & 7.000 & $8 \mathrm{~kg}$ & $9 \mathrm{~kg}$ & $9 \mathrm{~kg}$ \\
\hline $\begin{array}{l}\text { Brokoli } \\
\text { (per kg) }\end{array}$ & 46.000 & $10 \mathrm{~kg}$ & $12 \mathrm{~kg}$ & $15 \mathrm{~kg}$ \\
\hline
\end{tabular}

Sumber: Warung Sehat 1000 Kebun

Tabel 1. menunjukkan terdapat beberapa jenis sayuran organik yang dijual Warung Sehat 1000 Kebun Arcamanik, Bandung yang jumlah penjualannya mengalami perubahan setiap bulannya. Namun sayur organik yang paling banyak diminati konsumen adalah wortel organik dengan kisaran harga Rp 24.000/kg.

Berdasarkan pemaparan di atas penulis tertarik untuk meneliti mengenai kesediaan membayar konsumen milenial dalam mengkonsumsi sayuran organik dan faktor-faktor yang mempengaruhi konsumen dalam mengkonsumsi sayuran organik yang akan dilakukan pada salah satu ritel modern di kota Bandung yang menyediakan sayuran organik yaitu Warung Sehat 1000 Kebun Arcamanik, Bandung. Hal ini bertujuan untuk memberikan uraian mengenai kesediaan membayar konsumen milenial atas harga yang wajar sesuai dengan daya beli konsumen terhadap sayuran organik.

\section{METODE PENELITIAN}

Penelitian ini menggunakan pendekatan kuantitatis deskriptif dengan metode survei. Objek dalam penelitian ini adalah Kesediaan Membayar Generasi Milenial dalam Mengkonsumsi Sayuran Organik. Lokasi penelitian ini bertempat di salah satu ritel sayuran organik di Kota Bandung, yaitu Warung Sehat 1000 Kebun yang berada di Jalan Boling No.26 Arcamanik Kota Bandung. Pemilihan lokasi ini dilakukan secara terencana (purposive) sesudah melalui tahap survei berlandaskan keunggulan bahwa Warung Sehat 1000 Kebun merupakan ritel sayuran organik yang menjual produknya atas dasar 4 prinsip yaitu: kesehatan, keadilan, lingkungan, dan konservasi.

Variabel dalam penelitian ini terdiri: 1) Karakteristik konsumen yang terdiri dari jenis kelamin, usia, Pendidikan, pendapatan, dan tanggungan 
keluarga; 2) Faktor-faktor yang mempengaruhi konsumen dalam pembelian sayuran organik yang terdiri dari budaya, sosial, pribadi, psikologis dan sumber informasi; 3) Willingness to pay yang terdiri dari atribut produk, harga produk, keamanan produk, gaya hidup, dan jumlah konsumsi.

Teknik pengambilan sampel dalam penelitian ini menggunakan teknik nonprobability sampling yaitu accidental sampling. Hal ini bertujuan untuk peneliti hanya akan meneliti dan mengambil data berdasarkan responden yang dating pada saat dilakukan kegiatan penelitian secara langsung, dan memudahkan peneliti dalam memperoleh data penelitian. Populasi pada penelitian ini adalah konsumen warung sehat 1000 kebun. Jumlah sampel yang dibutuhkan untuk meneliti kesediaan konsumen milenial dalam mengkonsumsi sayuran organic di Warung Sehat 1000 Kebun yaitu sebanyak 93 responden.

Data dalam penelitian ini bersumber dari data primer dan data sekunder. Data primer diperoleh dari hasil observasi dan wawancara langsung terhadap responden. Data sekunder diperoleh dari sumber pustaka, seperti buku, internet, jurnal, dan lain sebagainya. Teknik pengumpulan data dilakukan melalui: 1) Wawancara dengan panduan kuesioner, dan 2) Pengamatan langsung (observasi) dilokasi penelitian.

Pengaruh karakteristik konsumen terhadap kesediaan membayar konsumen milenial dalam mengkonsumsi sayuran organik dilakukan dengan menggunakan analisis statistik deskriptif. Sedangkan untuk mengetahui pengaruh faktor budaya, sosial, pribadi, psikologis dan sumber informasi terhadap kesediaan membayar konsumen milenial dalam mengkonsumi sayuran organik digunakan analisis regresi linier berganda.

\section{HASIL DAN PEMBAHASAN}

Karakteristik konsumen dijelaskan berdasarkan karakteristik demografi yang terdiri dari jenis kelamin, usia, pendidikan terakhir, pekerjaan dan pendapatan. Adapun karakteristik konsumen yang ada pada Warung Sehat 1000 Kebun adalah sebagai berikut:

Tabel 2. Karakteristik Konsumen Berdasarkan Jenis Kelamin

\begin{tabular}{ccc}
\hline $\begin{array}{c}\text { Jenis } \\
\text { Kelamin }\end{array}$ & Frekuensi & Persentase \\
\hline Laki-laki & 75 & $80.1 \%$ \\
\hline Perempuan & 18 & $19.4 \%$ \\
\hline Total & 93 & $100 \%$ \\
\hline
\end{tabular}

Sumber: Hasil analisis data (2020)

Konsumen yang berbelanja sayuran organik di ritel Warung Sehat 1000 Kebun, $80.1 \%$ konsumen merupakan perempuan. Sedangkan sisanya sebesar 
19.4\% merupakan konsumen pria. Dapat disimpulkan bahwa sebagian besar pembeli sayuran organik di ritel Warung Sehat 1000 Kebun merupakan perempuan. Hal ini menunjukkan bahwa kegiatan berbelanja bahan makanan terlebih untuk produk sayuran sebagian besar merupakan aktivitas perempuan. Selain itu, menurut (Silalahi, 2012) mengatakan bahwa penyebab pelanggan yang berbelanja produk fresh food adalah perempuan karena sebagian besar kepala rumah tangga keluarga menyerahkan urusan berbelanja kebutuhan rumah tangga ke pihak perempuan.

Tabel 3. Karakteristik Konsumen Berdasarkan Usia Responden Milenial (19-38 Tahun) Terhadap Pembelian Sayuran Organik di Warung Sehat 1000 Kebun

\begin{tabular}{ccc}
\hline Usia & Frekuensi & Persentase \\
\hline $19-23$ tahun & 6 & $9.7 \%$ \\
\hline $24-28$ tahun & 67 & $72 \%$ \\
\hline $29-33$ tahun & 16 & $17.2 \%$ \\
\hline $34-38$ tahun & 1 & $1.1 \%$ \\
\hline Total & 93 & $100 \%$ \\
\hline
\end{tabular}

Sumber: Hasil analisis data (2020)

Konsumen yang melakukan pembelian sayur organik di ritel Warung Sehat 1000 Kebun berusia 24-28 tahun, dengan presentase sebesar $72 \%$. Menurut Erikson dalam Upton (2012), usia dewasa dibagi menjadi tiga tahap antara lain: 1) Masa dewasa awal (19 hingga 40 tahun), 2) Masa dewasa menengah (40 hingga 65 tahun), 3) Masa dewasa akhir (65 hingga mati). Selain itu, menurut penelitian Suprayitno dkk. (2015), pada usia dewasa pola berpikir lebih matang dibandingkan usia remaja terutama dalam memilih menu makanan. Biasanya usia dewasa lebih cenderung berpikir pola hidup sehat yaitu dengan memilih konsumsi makanan serba sayuran (vegetarian).

Tabel 4. Karakteristik Konsumen Berdasarkan Tingkat Pendidikan

\begin{tabular}{ccc}
\hline Pendidikan & Frekuensi & Persentase \\
\hline SD & 0 & $0 \%$ \\
\hline SMP & 0 & $0 \%$ \\
\hline SMA & 4 & $4.3 \%$ \\
\hline Diploma & 11 & $11.8 \%$ \\
\hline S1 & 76 & $81.7 \%$ \\
\hline S2/S3 & 2 & $2.2 \%$ \\
\hline Total & 93 & $100 \%$
\end{tabular}

Sumber: Hasil analisis data (2020)

Tingkat pendidikan didominasi oleh konsumen berpendidikan terakhir S1, dengan persentase sebesar $81.7 \%$. Hal ini terbukti dari data Statistik Gender Tematik Profil Generasi Milenial tahun 2017, menyatakan bahwa mayoritas pendidikan tertinggi penduduk generasi milenial adalah SMA/SMK/MA/sederajat dan presentasenya paling tinggi dibandingkan generasi lainnya, yakni sebesar 34,27 persen.

Tabel 5. Karakteristik Konsumen Berdasarkan Pekerjaan

\begin{tabular}{ccc}
\hline Pekerjaan & Frekuensi & Persentase \\
\hline Mahasiswa & 5 & $5.3 \%$ \\
\hline Karyawan Swasta & 30 & $32.3 \%$ \\
\hline Pegawai Negeri Sipil & 1 & $1 \%$ \\
\hline Ibu Rumah Tangga & 12 & $13 \%$ \\
\hline Lainnya & 45 & $48.4 \%$ \\
\hline Total & 93 & $100 \%$
\end{tabular}

Sumber: Hasil analisis data (2020)

Pekerjaan di ritel Warung Sehat 1000 Kebun didominasi oleh karyawan 
swasta yang berjumlah 30 orang dengan persentase sebesar $32.3 \%$. Hal diartikan bahwa pekerjaan dan keadaan ekonomi yang baik dapat mempengaruhi pola konsumsi, serta pendapatannya.

\begin{tabular}{|c|c|c|}
\hline $\begin{array}{l}\text { Tabel 6. } \quad \mathrm{Ka} \\
\text { Berdasarkan Tingka }\end{array}$ & $\begin{array}{l}\text { kteristik } \\
\text { Pendapatan }\end{array}$ & Konsumen \\
\hline Pendapatan & Frekuensi & Persentase \\
\hline$<\mathrm{Rp} 1.000 .000$ & 0 & $0 \%$ \\
\hline $\begin{array}{c}\mathrm{Rp} 1.000 .000-\mathrm{Rp} \\
3.000 .000\end{array}$ & 22 & $23.7 \%$ \\
\hline $\begin{array}{c}\mathrm{Rp} 3.000 .000-\mathrm{Rp} \\
6.000 .000\end{array}$ & 56 & $60.2 \%$ \\
\hline $\begin{array}{c}\mathrm{Rp} 6.000 .000-\mathrm{Rp} \\
9.000 .000\end{array}$ & 11 & $11.8 \%$ \\
\hline$>\operatorname{Rp} 9.000 .000$ & 4 & $4.3 \%$ \\
\hline Total & 93 & $100 \%$ \\
\hline
\end{tabular}

Sumber: Hasil analisis data (2020)

Konsumen yang membeli sayuran organik di Warung Sehat 1000 Kebun memiliki pendapatan berkisar $\mathrm{Rp}$ 3.000.000,00 hingga $\mathrm{Rp} 6.000 .000,00$ atau sekitar $60.2 \%$ dan konsumen sayuran organik sebagian besar adalah golongan berpendapatan menengah keatas di usia milenial. Menurut Firhas (2018), jumlah pendapatan menggambarkan seberapa besar upaya daya beli yang dilakukan konsumen, maka semakin tinggi tingkat pendapatan makan semakin tinggi pula kemampuan membeli seseorang.
Tabel 7. Jumlah Tanggungan Keluarga Konsumen Terhadap Pembelian Sayuran Organik

\begin{tabular}{ccc}
\hline Kategori & Frekuensi & Persentase \\
\hline Belum berkeluarga & 64 & $68.8 \%$ \\
\hline $\begin{array}{c}\text { Keluarga (jumlah } \\
\text { anggota keluarga } \\
<4 \text { orang) }\end{array}$ & 29 & $31.2 \%$ \\
\hline $\begin{array}{c}\text { Keluarga besar } \\
\text { (jumlah anggota } \\
\text { keluarga }>4\end{array}$ & 0 & $0 \%$ \\
\hline Total & 93 & $100 \%$ \\
\hline
\end{tabular}

Sumber: Hasil analisis data (2020)

Sebagian besar responden memiliki 3-4 orang anggota keluarga, yaitu sebesar 29 orang $(31.2 \%)$. Terdapat beberapa alasan responden untuk memilih mengkonsumsi sayuran organik namun, jumlah tanggungan keluarga yang dimiliki responden memengaruhi aspek kuantitas dan kualitas produk sayuran organik yang harus dibeli agar seluruh kebutuhan hidupnya dan keluarganya terpenuhi.

Tabel 8. Nilai Rataan Willingness to Pay Jenis Sayuran Organik yang dibeli Oleh Responden di Warung Sehat 1000 Kebun

\begin{tabular}{clcc}
\hline No & Jenis Sayuran & $\begin{array}{c}\text { Harga } \\
\text { (Rupiah) }\end{array}$ & $\begin{array}{c}\text { EWTP } \\
\text { (Rupiah) }\end{array}$ \\
\hline 1 & $\begin{array}{l}\text { Wortel } \\
\text { (per kg) }\end{array}$ & 24.000 & 3.892 \\
\hline 2 & Tomat (per kg) & 34.000 & 5.591 \\
\hline 3 & $\begin{array}{l}\text { Bayam Hijau } \\
\text { (pack@250gr) }\end{array}$ & 7.000 & 1.419 \\
\hline 4 & $\begin{array}{l}\text { Kentang } \\
\text { (per kg) }\end{array}$ & 34.000 & 4.570 \\
\hline 5 & $\begin{array}{l}\text { Pakcoy } \\
\text { (pack@250gr) }\end{array}$ & 7.000 & 1.237 \\
\hline 6 & $\begin{array}{l}\text { Kangkung (pack } \\
\text { @250gr) }\end{array}$ & 7.000 & 1.667 \\
\hline 7 & $\begin{array}{l}\text { Brokoli } \\
\text { (per kg) }\end{array}$ & 46.000 & 8.355 \\
\hline
\end{tabular}

Sumber: Hasil analisis data (2020)

Dari nilai rataan keseluruhan responden, maka dapat disimpulkan bahwa nilai WTP yang besar dan jumlah 
responden yang banyak menghasilkan nilai rataan WTP yang besar pula, begitupun sebaliknya. Dari total keseluruhan responden WTP (willingness to pay) cenderung mengkonsumsi jenis sayuran organik yang bervariatif. Berdasarkan penelitian yang telah dilakukan, penetapan Willingness to Pay responden memperlihatkan seberapa besar kesediaan responden dalam mengeluarkan biaya terhadap suatu produk pangan berlabel premium di atas harga produk pangan biasa lainnya. Eksistensi konsumen sayuran organik dan nilai kesediaan membayarnya dapat dijadikan sebagai critical point pemasaran sayuran organik di Warung Sehat 1000 Kebun.

Pengujian hipotesis dilakukan dengan menggunakan analisis regresi linier berganda. Metode Regresi Linier berganda ini dimaksud untuk mengetahui seberapa besar tingkat pengaruh antara Budaya (X1), Sosial (X2), Pribadi (X3), Psikologis (X4) dan Sumber Informasi (X5) WTP (Y).

Tabel 9. Hasil Uji Regresi Linier Berganda

\begin{tabular}{|c|c|c|c|c|c|}
\hline & \multicolumn{3}{|c|}{ Coefficients ${ }^{\mathrm{a}}$} & \multirow{3}{*}{$t$} & \multirow{3}{*}{ Sig. } \\
\hline \multirow[t]{2}{*}{ Model } & \multicolumn{2}{|c|}{$\begin{array}{l}\text { Unstandardized } \\
\text { Coefficients }\end{array}$} & $\begin{array}{l}\text { Standardized } \\
\text { Coefficients }\end{array}$ & & \\
\hline & B & Std. Error & Beta & & \\
\hline (Constant) & 1811.258 & 1798.091 & & \begin{tabular}{|l|l|}
1,007 & \\
\end{tabular} & .317 \\
\hline Budaya &, 817 &, 419 & ,327 & 1,951 &, 045 \\
\hline Sosial &,- 904 & ,337 &,- 474 & & ,009 \\
\hline 1 & & & & 2,681 & \\
\hline Pribadi & .463 & .203 & .225 & 2,286 & .025 \\
\hline Psikologis & ,628 &, 152 & ,418 & 4,126 &, 000 \\
\hline $\begin{array}{l}\text { Sumber } \\
\text { Informasi }\end{array}$ & ,478 &, 169 & ,277 & 2,820 & ,006 \\
\hline
\end{tabular}

Diketahui nilai constan (a) sebesar 1811,258 sedangkan nilai Budaya 0,817 Sosial -0,904, Pribadi 0,463, Psikologis 0,628, dan Sumber Informasi 0,478 sehingga persamaan regresinya dapat ditulis:

$$
\begin{aligned}
Y= & 1811,258+0.817 x_{1}+(-0.904) x_{2}+ \\
& 0.463 x_{3}+0.628 x_{4}+0.478 x_{5}
\end{aligned}
$$

Koefisien-koefisien persamaan regresi linier berganda di atas dapat diartikan koefisien regresi untuk konstanta sebesar 1811,258 mengandung arti bahwa nilai konsisten variabel WTP adalah sebesar 1811,258.

\begin{tabular}{|c|c|c|c|c|}
\hline \multicolumn{5}{|c|}{ Model Summary } \\
\hline Model & $\mathrm{R}$ & R Square & Adjusted R Square & Std. Error of the Estimate \\
\hline 1 & $.693^{a}$ & .481 & .451 & 2847,51502 \\
\hline
\end{tabular}

\section{Tabel 10. Hasil Uji R2}

Berdasarkan Tabel 10. diperoleh angka $\mathrm{R}^{2}$ (R Square) sebesar 0,481 atau $(48,1 \%)$. Hal ini menunjukkan bahwa persentase sumbangan pengaruh FaktorFaktor yang Mempengaruhi Konsumen dalam Pembelian Sayuran Organik (Budaya, Sosial, Pribadi, Psikologis, dan Sumber Informasi) terhadap kesediaan membayar sayuran organik sebesar $48,1 \%$. Sedangkan sisanya sebesar $51,9 \%$ dijelaskan atau dipengaruhi oleh variabel lain yang tidak diteliti. 
Tabel 11. Hasil Uji F

\begin{tabular}{|c|c|c|c|c|c|c|}
\hline \multicolumn{7}{|c|}{ ANOVA $^{\mathbf{a}}$} \\
\hline & & Sum of Squares & Df & Mean Square & $\mathrm{F}$ & Sig. \\
\hline \multirow{3}{*}{1} & Regression & 653248295,338 & 5 & 130649659,068 & 16,113 & $.000^{\mathrm{b}}$ \\
\hline & Residual & 705425733,780 & 87 & 8108341,768 & & \\
\hline & Total & 1358674029,118 & 92 & & & \\
\hline \multicolumn{7}{|c|}{$\begin{array}{l}\text { a. Dependent Variable: WTP } \\
\text { b. Predictors: (Constant), Sumb }\end{array}$} \\
\hline \multicolumn{7}{|c|}{ Sumber: Hasil analisis data (2020) } \\
\hline
\end{tabular}

Berdasarkan Tabel 11. diperoleh nilai Fhitung sebesar 16,113 dengan nilai Sig sebesar 0,000. Hal ini menunjukkan bahwa nilai Fhitung lebih besar dari FTabel 2,475 dan nilai Sig lebih kecil dari 0,05. Dengan demikian H0 ditolak dan Ha diterima. Artinya Budaya, Sosial, Pribadi, Psikologis, dan Sumber Informasi secara simultan mempunyai pengaruh yang signifikan terhadap kesediaan membayar sayuran organik.

Tabel 12. Hasil Uji T

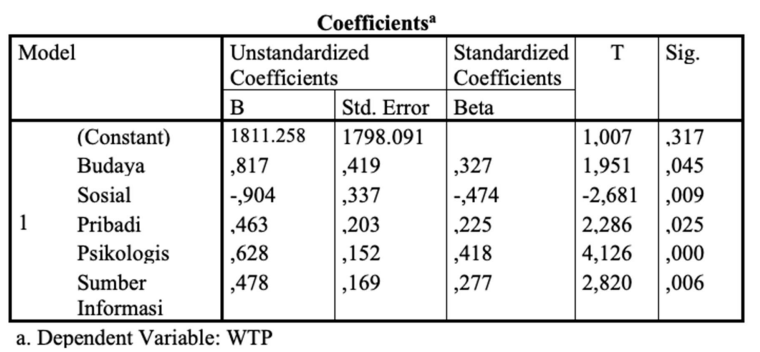

Sumber: Hasil analisis data (2020)

Dari hasil pengolahan didapatkan nilai signifikan variabel yang pertama mengenai budaya adalah 0,045 lebih kecil dari $\alpha=0.05(5 \%)$, artinya faktor budaya berpengaruh terhadap kesediaan membayar sayuran organik. Responden lebih banyak memilih setuju dengan variabel budaya karena suatu pengalaman, tren dan keinginan tidak dapat dipisahkan dari karakteristik budayanya. Dengan adanya budaya, generasi milenial lebih terdorong untuk mengkonsumsi sayuran organik. Sehingga konsumen generasi milenial tersebut bersedia membayar lebih untuk sayuran organik.

Budaya merupakan faktor penentu yang paling mendasar dari segi keinginan dan perilaku seseorang karena kebudayaan menyangkut segala aspek kehidupan manusia. Menurut kotler (2005:224) kebudayaan adalah determinan paling fundamental dari keinginan dan perilaku konsumen. Subbudaya terdiri dari kebangsaan, agama, kelompok ras, dan daerah geografis. Banyak sub-budaya yang membentuk segmen pasar penting, dan pemasar sering merancang produk dan program pemasaran yang disesuaikan dengan kebutuhan mereka. Keterkaitan karakteristik responden dengan faktor budaya yang berpengaruh positif terhadap keputusan pembelian juga dapat dilihat dari sisi produk sayuran organik yang disediakan oleh ritel Warung Sehat 1000 Kebun. Seperti kita ketahui sayuran organik merupakan bahan pangan yang bebas dari bahan kimia sehingga hal tersebut cocok untuk dijadikan sebuah alasan untuk mengurangi konsumsi makanan yang tidak sehat. 
Hasil Penelitian ini didukung oleh penelitian yang dilakukan oleh Puspita Rini (2013) mengenai pengaruh faktor kebudayaan, sosial, pribadi dan psikologis terhadap proses keputusan pembelian sayuran organik di Jl. Jendral Soedirman Yogyakarta. Menyatakan bahwa faktor budaya menjadi faktor yang paling dominan dan faktor yang paling utama mempengaruhi perilaku pembelian sayuran organik.

Berdasarkan hasil pengolahan didapatkan nilai signifikan variabel yang ketiga mengenai pribadi adalah 0,025 lebih kecil dari $\alpha=0.05$ (5\%), artinya faktor pribadi berpengaruh terhadap kesediaan membayar sayuran organik. Pada umumnya terdapat beberapa indikator faktor pribadi dalam keputusan pembelian diantaranya, kepribadian, pekerjaan, umur, dan kondisi ekonomi. Setiap individu memerlukan kebutuhan untuk menjalankan kehidupan sehariharinya. Dalam memenuhi kebutuhan tersebut setiap individu mengharuskan mencari pekerjaan untuk mendapatkan penghasilan (Putri dan Setiawan, 2013). Berdasarkan responden pada penelitian ini, didominasi oleh perempuan. Maka, pemenuhan kebutuhan suatu keluarga bergantung pada pendapatan diri sendiri dan keluarganya. Pendapatan merupakan faktor yang menentukan kualitas dan kuantitas makanan yang dikonsumsi. Semakin tinggi pendapatan semakin besar pula peluang untuk memilih makanan yang baik yaitu sayuran organik. Sejalan dengan perubahan pendapatan seseorang maka akan diikuti pula dengan perubahan dalam susunan makanan yang dikonsumsi. Setiap individu dengan status ekonomi yang tinggi akan lebih memperhatikan kandungan gizi dari makanan tersebut (Rachman, dkk., 2017). Responden dalam penelitian ini didominasi oleh konsumen yang bekerja sebagai wiraswasta dan berpenghasilan sekitar Rp 3.000.000 sampai Rp 6.000.000 sehingga mereka perlu menyesuaikan pengeluaran terutama untuk konsumsi harian, penghasilan tersebut juga berpengaruh terhadap kemampuan dan daya beli responden golongan milenial oleh karena itu respon para responden dalam memberikan jawaban yang berkaitan dengan variabel pengalaman kerja cenderung menghasilkan jawaban yang tidak positif.

Keadaan ekonomi, konsumen mengakui bahwa berbelanja sayuran organik di ritel Warung Sehat 1000 Kebun telah sesuai dengan keadaan ekonominya. Artinya, ketika seseorang melakukan kegiatan belanja sayuran 
organik di ritel Warung Sehat 1000 Kebun karena seseorang tersebut puas dengan apa yang dikeluarkan dan apa yang didapatkannya serta sesuai dengan situasi ekonominya saat itu. Situasi ekonomi seseorang dipengaruhi oleh pendapatannya, semakin tinggi pendapatannya maka situasi ekonominya semakin membaik, dan peluangnya untuk memutuskan pembelian sayur organik di Warung Sehat 1000 Kebun semakin besar. Hal tersebut sesuai dengan hasil penelitian ini dimana sebagian besar responden generasi milenial memiliki pendapatan lebih dari $\mathrm{Rp} 3.000,000,00$ dalam satu bulan. Sehingga dapat disimpulkan seseorang dengan situasi ekonomi yang lebih baik dengan pendapatan yang tinggi, dapat membuat keputusan pembelian sayuran organic di Warung Sehat 1000 Kebun memiliki daya beli yang besar. Hasil penelitian ini sejalan dengan penelitian yang dilakukan oleh Sakti (2018) mengenai Meningkatnya pendapatan merupakan faktor utama bagi seseorang untuk dapat membeli atau mengikuti seleranya, karena dengan pendapatan yang tinggi, kehidupan seseorang akan mementingkan kualitas dalam segi konsumsi terutama untuk konsumsi harian yaitu sayuran organik yang berfungsi bagi kesehatan.
Berdasarkan hasil pengolahan diperoleh nilai signifikan hipotesis yang keempat mengenai psikologis adalah 0,000 lebih kecil dari $\alpha=0.05(5 \%)$, artinya faktor psikologis berpengaruh terhadap kesediaan membayar sayuran organik. Artinya faktor psikologis berpengaruh terhadap kesediaan membayar sayuran organik. Menurut Lamb, dkk (2011), faktor psikologis dihasilkan dari interaksi seseorang dengan dunia dan lingkungannya masingmasing. Setiap orang memiliki sifat yang berbeda-beda dan berhadapan dengan kesempatan ataupun peristiwa yang berbeda-beda, sehingga menghasilakan faktor psikologis yang berbeda-beda pula.

Psikologis tersebut terdiri dari empat dimensi yaitu motivasi, persepsi, pengetahuan, dan keyakinan. Adanya motivasi dalam merubah pola konsumsi menjadi lebih sehat sangat mempengaruhi terhadap pembelian sayuran organik, semakin tinggi motivasi yang dimiliki oleh diri seorang konsmen, semakin tinggi pula peluang dalam membeli sayuran organik. Pada hakekatnya perbedaan persepsi akan berhubungan dengan perilaku seseorang dalam mengambil keputusan terhadap apa yang dikehendaki, persepsi juga akan membawa seseorang untuk termotivasi 
dalam melakukan suatu perbuatan. Persepsi konsumen terhadap mutu biasanya dipengaruhi oleh kualitas produk. Menurut Kotler dan Keller (2007), mutu produk dibagi menjadi dua yaitu mutu kinerja dan mutu kesesuaian. Mutu kinerja (performance), dimensi yang paling basic dan berhubungan dengan fungsi utama dari suatu produk sedangkan mutu mutu kesesuaian (conformance quality) adalah tingkat kesesuaian dan pemenuhan semua unit yang diproduksi terhadap spesifikasi yang dijanjikan. Jadi dapat disimpulkan bahwa suatu produk dikatakan mempunyai mutu yang baik apabila kualitas sayuran tersebut sudah sesuai dengan yang diharapkan oleh konsumen jika dilihat dari segi fungsinya.

Pengetahuan yang diterapkan secara akan memiliki efek pengalaman yang semakin bertambah. Keyakinana dalam pola konsumsi sehat dapat digambarkan dari tingkat kepastian konsumen Warung Sehat 1000 Kebun yang mempertimbangkan suatu merek dan produk yang benar secara evaluatif, apakah merek tersebut baik atau buruk untuk di konsumsi.

Hal ini sejalan dengan penelitian yang telah dilakukan oleh Tonny Affandy, dkk (2014) menyatakan bahwa faktor psikologis yang terbentuk dari lima faktor yaitu sikap, motivasi, pembelajaran, persepsi dan kepribadian berpengaruh signifikan secara parsial dan simultan terhadap keputusan pembelian.

Berdasarkan hasil pengolahan diperoleh nilai signifikan hipotesis yang kelima mengenai sumber informasi adalah 0,006 lebih kecil dari $\alpha=$ $0.05(5 \%)$, artinya faktor sumber informasi berpengaruh terhadap keputusan pembelian sayuran organik. Artinya, keputusan pembelian dapat dicapai jika sumber informasi memiliki konten yang baik dan menarik.

Semakin tinggi daya tarik sumber informasi maka sikap yang dibentuk konsumen akan semakin positif. Saat ini sebagian besar masyarakat khususnya golongan milenial menjadi pengguna yang terbilang sangat aktif di dunia maya. Bahkan saat ini media sosial kini menjadi rumah kedua bagi pengguna smartphone. Di Indonesia, generasi milenilan telah menjadikan media sosial menjadi sumber informasi utama. Konten media sosial yang disediakan oleh pihak Warung Sehat 1000 Kebun memberikan konten yang menarik dan disertai sumber informasi yang sangat lengkap mengenai produk-produk yang ada di warung sehat 1000 Kebun khususnya untuk komoditas 
sayuran organik. Hal ini menjadi salah satu alasan bahwa sumber informasi yang biasa diakses oleh konsumen akan membantu mendorong minat beli konsumen terhadap sayuran organik. Dengan sumber informasi yang lengkap, konsumen tidak perlu khawatir lagi akan kandungan sayuran organik yang bebas pestisida dan sejumlah manfaat yang dapat didapatkan dari komoditas pangan tersebut.

Hal ini juga sejalan dengan hasil penelitian yang dikemukakan oleh Wangenheim dan Bayon (2004), Kahle dan Homer (1985) yang juga mengemukakan bahwa daya tarik yang dimiliki oleh sumber informasi dalam persepsi konsumen akan membawa pada perubahan pada sikap konsumen yang juga membawa pada keinginan membeli konsumen.

Berdasarkan hasil pengolahan diperoleh nilai signifikan untuk variabel sosial adalah sebesar 0,009 lebih lebas dari $\alpha=0.05$ (5\%) dan t hitung sebesar 2,681 lebih besar dari pada t Tabel 1,661, artinya faktor sosial berpengaruh ke arah negatif terhadap keputusan pembelian dan kesediaan membayar sayuran organik. Pengaruh negatif mempunyai makna bahwa dalam kehidupan sosial responden yang diteliti tidak mendukung responden untuk mengkonsumsi sayuran organik, maka dari itu faktor sosial dalam penelitian ini dinyatakan berpengaruh terhadap keputusan pembelian dan kesediaan membayar sayuran organik akan tetapi karena minimnya dukungan sehingga faktor sosial ini berpengaruh negatif terhadap responden. Hasil dari observasi dilapangan menunjukkan sebagian besar responden menyatakan ketidaktahuan mengenai produk organik khususnya sayuran organik. Hal ini dikarenakan pihak instansi dan lingkungan sosial lainnya kurang optimal dalam memberikan edukasi dan sosialisasi mengenai manfaat sayuran organik bagi kesehatan.

Hal ini sejalan dengan adanya penelitian yang dilakukan oleh Ramadhani (2017) tentang "Faktor-faktor yang mempengarhi konsmsi sayur dan buah di Universitas Surakarta" bahwa faktor sosial tidak berpengaruh secara signifikan terhadap keputusan pembelian sayur dan buah. Hal ini disebabkan kurangnya program penyuluhan dalam bentuk menarik konsumen terhadap sayuran organik. 
Tabel 13. Jenis Sayuran dan rata-rata harga yang konsumen bersedia bayarkan

\begin{tabular}{clccc}
\hline No & $\begin{array}{l}\text { Jenis } \\
\text { Sayuran }\end{array}$ & $\begin{array}{c}\text { Harga } \\
\text { (Rupiah) }\end{array}$ & $\begin{array}{c}\text { Harga yang } \\
\text { bersedia } \\
\text { dibayarkan }\end{array}$ & $\begin{array}{c}\text { Nilai } \\
\text { WTP }\end{array}$ \\
\hline $\mathbf{1}$ & $\begin{array}{l}\text { Wortel } \\
\text { (per kg) }\end{array}$ & 24.000 & 20.108 & 3.892 \\
\hline $\mathbf{2}$ & $\begin{array}{l}\text { Tomat } \\
\text { (per kg) }\end{array}$ & 34.000 & 28.409 & 5.591 \\
\hline $\mathbf{3}$ & $\begin{array}{l}\text { Bayam } \\
\text { Hijau } \\
\text { (pack } \\
\text { @2,250gr) }\end{array}$ & 7.000 & 5.581 & 1.419 \\
\hline $\mathbf{4}$ & $\begin{array}{l}\text { Kentang } \\
\text { (per kg) }\end{array}$ & 34.000 & 29.430 & 4.570 \\
\hline $\mathbf{5}$ & $\begin{array}{l}\text { Pakcoy } \\
\text { (pack } \\
\text { @250gr) }\end{array}$ & 7.000 & 5.763 & 1.237 \\
\hline $\mathbf{6}$ & $\begin{array}{l}\text { Kangkun } \\
\text { (pack } \\
\text { @250gr) }\end{array}$ & 7.000 & 5.333 & 1.667 \\
\hline $\mathbf{7}$ & $\begin{array}{l}\text { Brokoli } \\
\text { (per kg) }\end{array}$ & 46.000 & 37.742 & 8.355 \\
\hline
\end{tabular}

Sumber: Hasil analisis data (2020)

Berdasarkan Tabel 13. dapat disimpulkan bahwa sebagian besar responden bersedia membayar kurang dari harga Warung Sehat 1000 Kebun untuk mendapatkan produk sayur organik.

Sebagian besar konsumen generasi milenial Warung Sehat 1000 Kebun mampu membayar dengan harga yang telah ditetapkan, karena berdasarkan pernyataan responden bahwa ritel Warung Sehat 1000 Kebun tergolong ritel produk sayuran organik dengan harga yang murah dibandingkan ritel lainnya di Kota Bandung. akan tetapi konsumen generasi milenial mengharapkan harga sayuran organik di ritel Warung Sehat 1000 Kebun dapat sesuai dengan daya beli generasi mienial. Hal ini sesuai dengan pendapat Krystallis dan Chryssohoidis (2005) yang menyatakan bahwa pada studi pengukuran WTP, proporsi responden yang bersedia membayar dengan harga tinggi untuk produk pangan dengan kualitas baik.

\section{KESIMPULAN DAN SARAN}

Karakteristik konsumen pada ritel Warung Sehat 1000 Kebun didominasi oleh jenis kelamin perempuan, dengan usia rata-rata berkisar pada 24-28 tahun yang termasuk ke dalam dewasa awal. Pendidikan terakhir konsumen didominasi oleh Pendidikan S1, untuk pekerjaan konsumen paling banyak mengemban pekerjaan sebagai karyawan swasta dengan rata-rata penghasilan ada pada kisaran Rp 3.000.000-Rp 6.000.000 per bulan. Rata-rata konsumen belum mempunyai tanggungan keluarga (single).

Nilai rata-rata willingness to pay konsumen generasi milenial dalam membeli sayuran organik adalah sebagai berikut: wortel Rp 3,892, tomat Rp 5.591, bayam hijau Rp 1.419, kentang Rp 4.570, pakcoy Rp 1.237, kangkung Rp 1,667 dan brokoli Rp 8.355 .

Faktor yang mempengaruhi kesediaan membayar konsumen golongan milenial dalam berbelanja sayuran organik di ritel Warung Sehat 1000 Kebun terdiri dari faktor budaya, faktor 
sosial, faktor pribadi, faktor psikologis dan faktor sumber informasi. Dengan urutan faktor yang paling berpengaruh sampai yang paling sedikit pengaruhnya, yaitu sebagai berikut: 1) Faktor psikologis, nilai sig $0,000<0,05 ; 2$ ) Faktor Sumber informasi, nilai sig $0,006<0,05$; 3) Faktor Sosial, nilai sig $0,009<0,05$; 4) Faktor Pribadi, nilai sig $0,025<0,05$; 5) Faktor Budaya, nilai sig $0,045<0,05$.

Adanya nilai WTP yang cukup besar diartikan sebagai ketidakcocokan harga antara yang dikeluarkan oleh produsen dan yang diterima oleh konsumen. Sehingga perusahaan perlu mengkaji ulang harga yang ditetapkan untuk semua produk yang dijual khususnya pada sayuran organik. Sehingga diharapkan dengan adanya keselarasan harga yang tidak memberatkan salah satu pihak, dapat meningkatkan pembelian sayuran organik di ritel Warung Sehat 1000 Kebun.

Faktor psikologis merupakan variabel terbesar yang mempengaruhi keputusan pembelian di ritel Warung Sehat 1000 Kebun. Hal ini perlu disikapi dengan lebih mempertahankan dan meningkatkan motivasi kepada diri sendiri dalam merubah pola hidup sehat. Selain itu juga menjadikan persepsi sebagai pembawa motivasi untuk masyarakat lainnya agar termotivasi dalam mengkonsumsi sayuran organik, dan memberikan pengetahuan mengenai manfaat dan juga vitamin yang ada pada sayuran organik.

Dikarenakan persentase sumbangan pengaruh faktor-faktor yang mempengaruhi konsumen dalam pembelian sayuran organik (budaya, sosial, pribadi, psikologis, dan sumber informasi) terhadap kesediaan membayar sayuran organik sebesar 48,1\%. Maka disarankan untuk penelitian selanjutnya menambahkan faktor yang belum ada di dalam penelitian ini, seperti faktor dampak kesehatan (Umi Rofiatin, 2018), faktor sikap yang terdiri dari dua indikator yaitu percaya dan kesehatan lingkungan (Priambodo Lutfhan Hadhi, 2014), dan faktor terakhir yaitu kepedulian (Is Wahyuni Yunus, 2019).

\section{DAFTAR PUSTAKA}

Rofiatin Umi, Bariska Hanif Fitri. 2018. Pola Willingnes To Pay (WTP) dan Faktor-Faktor Yang Mempengaruhi Terhadap Pilihan Sayur Organik dan Anorganik Masyarakat Kota Malang. Jurnal Ilmiah. Program Studi Agribisnis, Ekonomi dan Sosial. Fakultas Pertanian. Universitas Tribhuwana Tunggadewi.

Badan Pusat Statistika. 2018. Profil Generasi Milenial Indonesia 2018. 
Jakarta: Badan Pusat Statistika

Badan Pusat Statistik. 2017. Pengeluaran

Rata-rata Per Kapita Seminggu

Untuk Mengkonsumsi Sayuran di Indonesia. 2017 \& 2018. Jakarta: Badan Pusat Statistika

Aliansi Organis Indonesia. 2010. Statistik Pertanian Organik Indonesia (SPOI) 2010. Jakarta: AOI

Khorniawati Melisa. 2014. Produk Pertanian Organik di Indonesia: Tinjauan Atas Preferensi Konsumen Indonesia Terhadap Produk Pertanian Organik Lokal. Jurnal Ilmiah. Universitas Ma Chung

Mieke Ameriana. 2004. Kesediaan
Konsumen Untuk Membayar Premium serta Kepedulian Petani Terhadap Usaha Pengurangan Residu Pestisida pada Sayuran Tomat. Disertasi Doktor Program Pascasarjana Universitas Padjadjaran.

Satrio, Samsudin. 2004. Kiat Bercocok Tanam Sayuran Organik. Jakarta: Dhuafa Republika

Steenkamp, J.B.E.M dan H.C.M van Trijp. 1898. A Methodology for estimating the Maximum Price Consumers Are Willing to Pay in Relation to Perceived Quality and Consumer 